\title{
Impacts of dam construction on river channel evolution: a case of Minjiang River in Southeastern China
}

\author{
Ying Yao ${ }^{1}$, Wei Cui ${ }^{1}$, Wen Wang ${ }^{1}$, Fu-Min $\mathrm{Ma}^{2}$, and Ben-Yue Chen ${ }^{2}$ \\ ${ }^{1}$ State Key Laboratory of Hydrology-Water Resources and Hydraulic Engineering Sciences, \\ Hohai University, Nanjing, China \\ ${ }^{2}$ Bureau of Hydrology and Water Resources of Fujian Province, Fuzhou, China \\ Correspondence: Wen Wang (w.wang@126.com) \\ Published: 16 September 2020
}

\begin{abstract}
The Minjiang River is the largest river in Fujian Province. In 1993, the Shuikou Reservoir, which has an effective storage capacity of 700 million $\mathrm{m}^{3}$, was built at about $161 \mathrm{~km}$ above the estuary. The completion of the Shuikou Dam trapped most of the upstream sediment in the reservoir area, resulting in a drastic decrease in sediment in the lower reaches of the Minjiang River. The average annual sand load at the Zhuqi Station (about $45 \mathrm{~km}$ below the dam) was reduced about $2 / 3$ after the construction of the reservoir, from 7.42 to 2.55 million $\mathrm{t}$ by average, resulting in severe river bed downward cutting. At the same time, the demand for the sand in Minjiang River channel is increasing year by year. The amount of mined river sand is greater than the incoming sediment deposited in the river, which intensified the downcutting of the river bed. The downcutting leads to a continuous upward movement of the tide limit in the river channel especially in the low-flow season. Meanwhile, river embankments and river-related structures are damaged, and the navigation capacity of the Minjiang River is reduced. At present, the river bed of the lower Minjiang River is not yet stable, and the river regime is in a state of constant adjustment.
\end{abstract}

\section{Introduction}

The Minjiang River is the largest river in Fujian Province, and 8 large reservoirs with capacity over 100 million $\mathrm{m}^{3}$ were built in the basin over the last 60 years. Among them, Shuikou Reservoir is the largest one, with a total capacity of 2.6 billion $\mathrm{m}^{3}$, which controlled $86 \%$ of the drainage area. It is known that the construction of reservoir dams will cause changes in the river runoff process, reducing the peak flows and increasing the low flows (Wang et al., 2011). At the same time, it will result in changes of downstream river flow regimes, riverbed scouring and river bank erosion, causing problems such as salt tide intrusion, river bank and bridge damage (Magilligan and Nislow, 2005). For example, after the closure of the Three Gorges Dam in China, various significant downstream changes are observed, such as sediment reduction (Yang et al., 2007), channel adjustment (Chen et al., 2007; Xia et al., 2016), riverbed erosion (Zheng et al., 2018), delta recession (Luo et al., 2017), flood pulse re- duction (Yang et al., 2015), and decline of riverine wetland and lake areas (Zhou et al., 2016). After the completion of Shuikou Dam in 1993, the river channel in the lower reaches of the Minjiang River was continuously eroded, and the salt tide kept moving upward (Huang, 2010). In the present study, we will investigate the downstream hydrological alteration and river channel evolution of the Minjiang River after the construction of Shuikou Reservoir, and the related impacts on the lower reaches.

\section{Hydrological characteristics of the Minjiang River}

\subsection{Introduction about the Minjiang River basin}

The Minjiang River flows into the east China sea, with a total length of $541 \mathrm{~km}$ and a total drainage area of $60992 \mathrm{~km}^{2}$. It originates from the Wuyi mountain range. The topography of the basin is high in the northwest and low in the southeast. The average slope of the river is $5 \%$. The basin is located in the subtropical monsoon climate zone with a warm and 


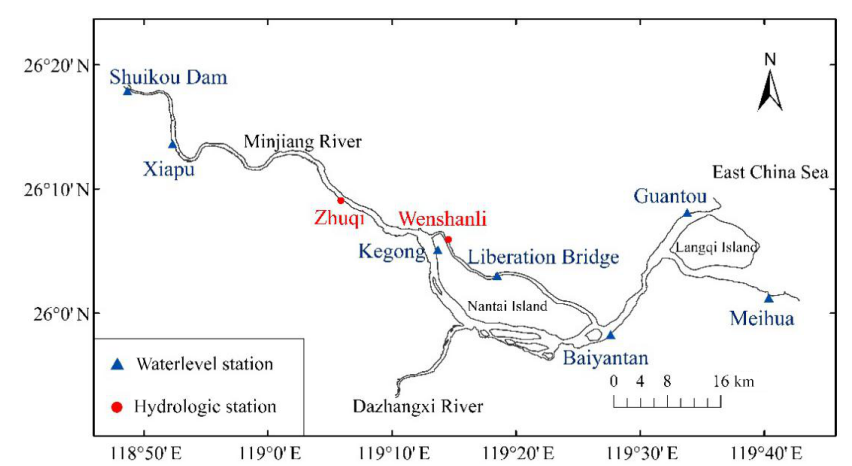

Figure 1. The lower reaches of the Minjiang River.

humid climate. The average annual temperature is about $17-$ $19^{\circ} \mathrm{C}$. The average annual precipitation in the basin is about $1600-1700 \mathrm{~mm}$, declining gradually from upper parts in the mountains to the lower parts along the coast.

The Shuikou Dam is located about $117 \mathrm{~km}$ above the Minjiang River estuary. The construction of Shuikou Dam started in March 1987, and its impoundment began in March 1993. The Shuikou Reservoir has a maximum storage capacity of 2.6 billion $\mathrm{m}^{3}$ and an effective storage capacity of 700 million $\mathrm{m}^{3}$. The drainage area above the reservoir dam site is $52438 \mathrm{~km}^{2}$, accounting for $86 \%$ of the total basin area. The reservoir is mainly used for hydroelectricity, also used for flood control and navigation.

\subsection{Hydrological characteristics of the river basin}

The Minjiang River Basin has an average annual runoff of about 57.34 billion $\mathrm{m}^{3}$ and an average runoff depth of $980 \mathrm{~mm}$ (China Ministry of Water Resources, 2017). The period during April to September is the flood season, and the runoff takes up about $75 \%$ of the total annual runoff. The maximum monthly runoff occurs in June, when the main flood season in the river basin comes. From October to March of the following year, it is the dry season, and the average annual runoff reaches the minimum in January. The lower reaches of the Minjiang River are often struck by heavy typhoon rains during July to September, causing severe floods. The Minjiang River estuary is a tidal estuary with strong tidal effects, and the tide type is normal semi-diurnal tide. According to the tidal data statistics in 2001, the average high tide level of Baiyantan station is $4.67 \mathrm{~m}$, the average low tide level is $0.82 \mathrm{~m}$, and the average tidal range is $2.55 \mathrm{~m}$. The maximum tidal range of the estuary is $7.04 \mathrm{~m}$, and the average tidal range is $4.1 \mathrm{~m}$. The tidal level increases from the estuary to the upstream, while the tidal amplitude decreases, and the tidal effects decreases.

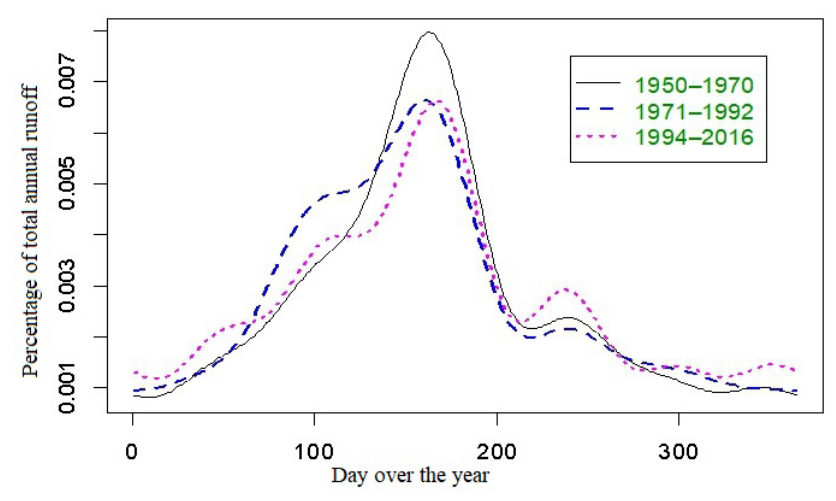

Figure 2. Variation of average daily discharge during three different periods since 1950 .

\section{Impacts of Shuikou Reservoir on riverflow and sediment process in the lower reaches of Minjiang River}

\subsection{Flow process change}

Because the capacity of Shuikou reservoir takes about only $4.5 \%$ of the average annual runoff of the Minjiang River, Shuikou reservoir has very little impact on the variation of annual runoff of Minjiang River, but the operation of Shuikou reservoir modified the seasonal variation of the runoff. The variation of average daily discharge at Zhuqi Station during three different periods since 1950 is shown in Fig. 2. As shown in Fig. 2, after the construction of Shuikou Dam, during the river flow rising period during March and July, the reservoir stores water, consequently reduces the outflow from the reservoir. During the period when river flow doing down and in low-flow period, the runoff below the Shuikou Dam increased due to increased outflow from the reservoir.

According to the naturalized monthly average flow data at Zhuqi from 1954 to 2004, the minimum monthly average flow before the construction of the Shuikou reservoir was $259 \mathrm{~m}^{3} \mathrm{~s}^{-1}$ in January 1968; and the minimum monthly average flow after the construction of the reservoir was $309 \mathrm{~m}^{3} \mathrm{~s}^{-1}$ in December 2003. In a word, the regulation of Shuikou reservoir makes the runoff tend to be slightly more evenly distributed over the year, but because the reservoir capacity is far less than the total annual runoff, so the effect on the downstream runoff is not obvious.

\subsection{Water level change}

The lowest water level at several locations along the lower reach of the Minjiang River (see Fig. 3) shows that, the lowest water level of the lower reach has decreased significantly since late 1980s', except at the estuary (Baiyantan). The decline of the water level accelerated in the late 1990s.

A further Comparison of the average water level in 1998, 2006 and 2010 and the corresponding water level changes at 




Figure 3. The variation of the lowest water level along the lower reach of the Minjiang River.

Table 1. Comparison of water levels at the same discharge at Zhuqi in different years.

\begin{tabular}{lrrrrr}
\hline $\begin{array}{l}\text { Discharge at Zhuqi } \\
\left(\mathrm{m}^{3} \mathrm{~s}^{-1}\right)\end{array}$ & $\begin{array}{r}\text { Water level } \\
\text { in } 1998(\mathrm{~m})\end{array}$ & $\begin{array}{r}\text { Water level } \\
\text { in 2006 }(\mathrm{m})\end{array}$ & $\begin{array}{r}\text { Water level } \\
\text { in 2010 }(\mathrm{m})\end{array}$ & $\begin{array}{r}\text { Water level difference } \\
\text { between 2006 and 1998 }\end{array}$ & $\begin{array}{r}\text { Water level difference } \\
\text { between } 2010 \text { and } 1998\end{array}$ \\
\hline 5000 & 7.18 & 3.91 & & 3.27 & 2.77 \\
10000 & 9.32 & 6.55 & 5.00 & 2.49 & 4.32 \\
15000 & 10.84 & 8.35 & 6.70 & 2.53 & 3.96 \\
20000 & 12.16 & 9.63 & 8.20 & 2.54 & 3.63 \\
25000 & 13.30 & 10.76 & 9.67 & & \\
\hline
\end{tabular}

the same discharge at Zhuqi are shown in Table 1. It can be seen that at Liberation Bridge (downstream) and Zhuji there has been a significant and sustained decline in water levels since 1970s'; decline has also occurred at Wenshanli since 1985 and the Liberation Bridge since 1995. Such changes are mostly caused by the gradual change of the riverbed due to the joint effects of reducing sediment by upstream reservoirs, whereas the sudden change in 1995 is caused by the removal of the pier of the old bridge.

\subsection{Variation in sediment volume}

According to the observation at Zhuqi, before the construction of Shuikou reservoir, the average suspended sediment concentration was $0.129 \mathrm{~kg} \mathrm{~m}^{-3}$ during the period from 1951 to 1992 with a maximum of $0.262 \mathrm{~kg} \mathrm{~m}^{-3}$ in 1962 and the minimum of $0.064 \mathrm{~kg} \mathrm{~m}^{-3}$ in 1991 , and the average suspended sediment transport capacity during 1951 to 1975 was 7.42 million t every year. After the completion of Shuikou reservoir, the average suspended sediment concentration at Zhuqi was $0.035 \mathrm{~kg} \mathrm{~m}^{-3}$, with a maximum of $0.135 \mathrm{~kg} \mathrm{~m}^{-3}$ in 2010 and a minimum of $0.007 \mathrm{~kg} \mathrm{~m}^{-3}$ in 2008 , and the average annual suspended sediment transport capacity de- creased to 2.55 million t during 1993 to 2016 . That is, by average 4.87 million $t$ suspended sediment are deposited in the reservoir every year.

It can be seen from the Table 2 that the proportion of suspended sediment with a size $>0.1 \mathrm{~mm}$ significantly reduced after the impoundment of Shuikou Dam. The decrease in the median grain size of sediments in the downstream reaches after dam construction is a common phenomenon observed in many rivers, e.g. the middle reaches of the Yangtze River below the Three Gorges Dam (Chu et al., 2007) and the lower reaches of the Yellow River below the Xiaolangdi Reservoir (Qu et al., 2010), because there are more coarse particles than fine particles deposited in the reservoir.

The ratio of the bed load to the suspended load in the mountainous rivers in Fujian Province is about 0.3, and the average bed load at Zhuqi before the construction of the Shuikou Dam is about 2.2 million t. After the dam construction, due to the reservoir's impounding effect, these bed load sediments are almost all deposited in the upper reaches of the Shuikou Reservoir. Therefore, after the completion of the reservoir, an average of 7.07 million t of sediment per year (including 4.87 million $t$ of suspended sediment and all of the bed load) are deposited in the reservoir. 
Table 2. Particle size composition of suspended sediment of Minjiang River at Zhuqi before and after Shuikou reservoir impoundment.

\begin{tabular}{lrrrrrrrrr}
\hline Year & \multicolumn{7}{c}{ Percentage of particles less than a certain size } \\
\cline { 2 - 9 } & $\begin{array}{r}0.005 \\
(\mathrm{~mm})\end{array}$ & $\begin{array}{r}0.010 \\
(\mathrm{~mm})\end{array}$ & $\begin{array}{r}0.025 \\
(\mathrm{~mm})\end{array}$ & $\begin{array}{r}0.050 \\
(\mathrm{~mm})\end{array}$ & $\begin{array}{r}0.10 \\
(\mathrm{~mm})\end{array}$ & $\begin{array}{r}0.25 \\
(\mathrm{~mm})\end{array}$ & $\begin{array}{r}0.50 \\
(\mathrm{~mm})\end{array}$ & $\begin{array}{r}1.0 \\
(\mathrm{~mm})\end{array}$ \\
\hline 1992 (Before impoundment) & 1.7 & 6.2 & 10.8 & 22.3 & 94.4 & 99.0 & 99.9 & 100 \\
1994 (After impoundment) & 1.3 & 6.3 & 11.8 & 26.9 & 95.8 & 99.5 & 100 & \\
\hline
\end{tabular}

The reduction of sediment downstream is a common phenomenon after dam construction. For example, after the closure of the Three Gorges Dam (TGD) in 2003 the sedimentation in the lower reaches of the Yangtze River decreased by $55 \%$ compared with $1993-2002$, and $65 \%$ of the pre- to post-TGD decrease in sediment flux can be attributed to the TGD (Yang et al., 2015).

While the sedimentation below the Shuikou Dam, there is a huge demand for river sand, and large-scale sand mining occurred in the lower reaches of the Minjiang River. The annual river sand consumption in the lower Minjiang is more than 10 million $\mathrm{t}$, which is more than sedimentation of the lower Minjiang. That seriously deepened the riverbed, endangered the stability of the river embankment and the safety of navigation.

\section{River channel evolution in the lower reaches of Minjiang River under the influence of Shuikou Reservoir}

Due to the changes in discharge and sedimentation caused by the construction of Shuikou Dam, jointly with the influence of human sand mining activities, the shape of the riverbed in the lower reaches of the Minjiang River is constantly changing. Such kind of changes is especially exhibited in the profound changes in the thalweg of Minjiang River.

After the Shuikou Reservoir was completed, the plane position of the thalweg at many river cross-sections in the lower reach of the Minjiang River got deeper generally and oscillated to varying degrees. For example, the riverbed the reach from Shuikou dam site to the south and north distributaries of the lower Minjiang River decreased by $4.64 \mathrm{~m}$ from 1989 to 2015. As shown in Fig. 4, the maximum incision depth in the riverbed during 2000 and 2015 exceeds 20 meters at Zhuqi. Figure 5 shows the changes of the thalweg of the lower reaches of the Minjiang River from the Shuikou Dam to the estuary in 2011 and 2015. It can be seen that the riverbed is still in a process of scouring deep $20+$ years after the dam was built.

River channel erosion below dams is a common phenomenon all over the world (Basson, 2012). Similar to the impact of the construction of the Shuikou Reservoir in the Minjiang River, many examples of serious channel incision below dams in relation to regional geographic conditions: e.g. 6 m, Davis Dam, Colorado River, USA (Kondolf,

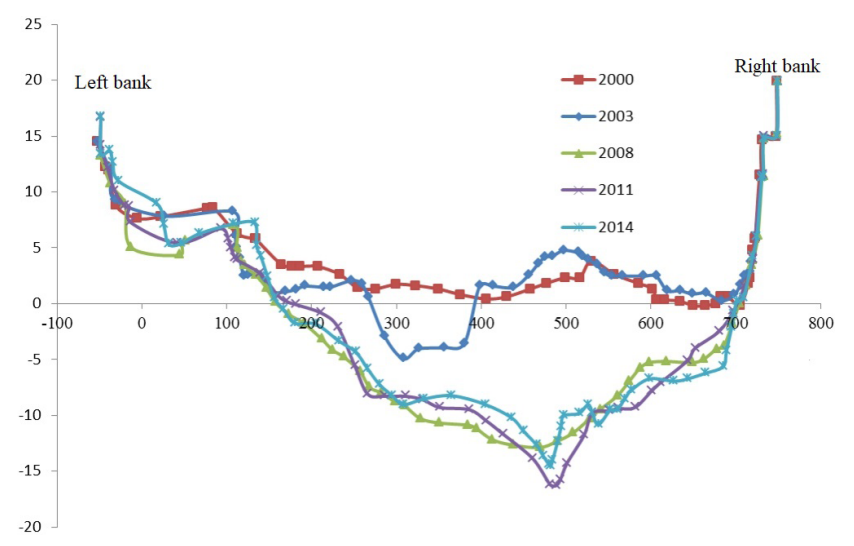

Figure 4. River bed elevation at the cross-section (from the left bank to the right bank) of the Minjiang River at Zhuqi in different years.

1997); 7.5 m, Hoover Dam, Colorado River, USA (Basson, 2012); 6 m, Saulspoort Dam, Ash River, South Africa (Basson, 2012); $10 \mathrm{~m}$, Three Gorges Dam, China (Zheng et al., 2018). However, bed erosion is not the only possibility and local conditions may determine a variety of outcomes (Lai et al., 2017) in terms of the incision depth or the time to reach a new balance between erosion and deposition. A recent study showed that the new long-term hydro-morphological equilibrium may have been established in the middle and lower Yangtze about 14 years after the closure of TGD (Lai et al., 2017). In the case of the Shuikou Dam, such a new equilibrium is still yet to be achieved. Although after 2008 the overall elevation of the riverbed got more or less stable at Zhuqi (as shown in Fig. 4), the thalweg is still getting deeper generally along the lower Minjiang (Fig. 5).

\section{Impacts of river evolution}

\subsection{Exacerbation of salt tide intrusion}

The Minjiang Estuary is a tidal estuary with strong regular semi-diurnal tides. In the estuary, the salt water is mixed up with fresh water, and the salinity of the water varies with runoff and tidal currents. In recent years, as the riverbed has been cut downward year by year, the amount of tides in the riverbed has been increasing, and the tidal current limit and the boundary of the tide have been continuously moving up- 




Figure 5. Comparison of thalwegs of the lower Minjiang River in 2011 and 2015.

stream. In the early 1990s, the tidal limit of Minjiang estuary in dry season was near Houguan $(68 \mathrm{~km}$ from the estuary) and the tidal current limit to Hongshan Bridge (58 km from the estuary). After the completion of the Shuikou Dam in August 1993, according to the measurement in the lowflow period in December 1996 and September 2002, the tidal limit was extended upward to Baitou $(72.5 \mathrm{~km}$ from the estuary), and the tidal current limit raised to Huai' an $(62.5 \mathrm{~km}$ from the estuary). In 2009, the tidal limit reached the Shuikou Dam (117 km above the estuary), and the tidal current limit reached Meixikou (about $102 \mathrm{~km}$ above estuary). As the tidal current limit kept moving upstream, 11 of the 12 water intakes of the downstream water plants along the lower Minjiang river are affected by the salty tide, and the closer the water plant is located to the river mouth, the more serious is the salt tide impact. At the same time, under the influence of the tidal current, the exchange time of the water body in the estuary is lengthened, the pollutants in the water body stay for a longer time than before. With the discharge of industrial waste and sewage from Fuzhou, which covers both sides of the lower reaches of the Minjiang River, the water environment problem in the lower reaches of the Minjiang River tends to be worsened.

\subsection{Damage of river-related structures}

After the operation of Shuikou Reservoir, the hydro-dynamic conditions of the rivers in the lower reaches of the Minjiang River have undergone great changes. In addition, the substantial reduction of river bed sediment leads to serious downcutting and riverbank erosion in the downstream river channel, resulting in damages to many bridges and ports, and putting some river embankments in dangers. For example, large scale landslides occurred on the bank near Dukou Village in Minqing County in 2005, near Huangguan Village in Minhou County in 2006, near Beixi Village in Minqing County in 2007. The occurrences of these dangers are great related to the river channel evolution and riverbed incision in the lower reaches of the Minjiang River. The further river bed incision in the lower reaches of the Minjiang River will further damage the riverbank stability and flood control safety.

\subsection{Reduction of river navigation capacity}

Due to dramatic decrease of the sediment in the lower Minjiang River after the completion of the Shuikou Reservoir and the excessive river sand mining in recent years, the river flow pattern changed, the riverbed geomorphology kept modifying, and the water level in the lower reaches decreased significantly, consequently the navigation was greatly affected. Before 1993, the navigation capacity of the Minjiang River was Class 3 (i.e., navigable for $1000 t$ ship). The Shuikou Reservoir was originally designed as a waterway with Class 4 standard (i.e., navigable for $500 \mathrm{t}$ ships) but with some room for extra navigation capacity. When the discharge flow rate is $308 \mathrm{~m}^{3} \mathrm{~s}^{-1}$, the bottom of the navigation lock is $3 \mathrm{~m}$ deep beneath the water level, which allows all ship passing. In recent years, due to the sharp incision of the riverbed of the Minjiang River channel, the navigation flow in the lower reaches of the Minjiang River has been increased year by year from the original design of 308 to $800 \mathrm{~m}^{3} \mathrm{~s}^{-1}$ in 2000 , $1500 \mathrm{~m}^{3} \mathrm{~s}^{-1}$ in $2004,2000 \mathrm{~m}^{3} \mathrm{~s}^{-1}$ in $2005,2350 \mathrm{~m}^{3} \mathrm{~s}^{-1}$ in 2006, and $3800 \mathrm{~m}^{3} \mathrm{~s}^{-1}$ in 2017. It is expected that the navigation capacity may be reduced in the future.

\section{Conclusion}

The construction of the cascade hydropower stations in the upper reaches of the Minjiang River, especially the Shuikou Reservoir began operation in 1993, modified the flow processes, trapped most sediment in the reservoir, and greatly reduced the amount of sediment transporting downstream. Such reduction of sediment together with excessive sand mining in the lower Minjiang River resulted in the severe downcutting of the riverbed and continuous river channel evolution of the lower Minjiang River. Due to such kind of river bed downward scouring and river bed evolution, the salty tide limit kept moving upward, river embankments and river-related structures are damaged, the navigation capac- 
ity of the Minjiang River are reduced. At present, the flowsediment situation in the lower reaches of the Minjiang River has not reached equilibrium, and the river channel is still in the process of evolving dominated by downward cutting.

Data availability. The internal data of the project is not convenient to be published.

Author contributions. YY, WC, and WW designed research, performed research, analyzed data. YY wrote the paper and WC and WW modified the paper. FMM and BYC participated in project research and data processing.

Competing interests. The authors declare that they have no conflict of interest.

Special issue statement. This article is part of the special issue "Hydrological processes and water security in a changing world". It is a result of the 8th Global FRIEND-Water Conference: Hydrological Processes and Water Security in a Changing World, Beijing, China, 6-9 November 2018.

\section{References}

Basson, G. R.: Sedimentation and sustainable use of reservoirs and river systems, Kyoto, ICOLD (International Committee on Large Dams), Bulletin 147, 2012.

Chen, Z., Chen, D., Xu, K., Zhao, Y., Wei, T., Chen, J., Li, L., and Watanabe, M.: Acoustic Doppler current profiler surveys along the Yangtze River, J. Geomorphology, 85, 155-165, https://doi.org/10.1016/j.geomorph.2006.03.018, 2007.

China Ministry of Water Resources: Bulletin of Chinese River Sediment, Beijing, China Water and Power Press, 2017 (in Chinese).

Chu, Z. X., Zhai, S. K., Zhang, L., and Dong, M.: Effects of Three Gorges Reservoir water storages in 2003 on the median grain size of suspended sediment of the Yangtze River, J. T. Ocean. Limnol., 23-28, https://doi.org/10.1007/978-3-540-72108-6_3, 2007 (in Chinese).

Huang, Y. F.: Study on bed evolution and its influence in the lower Minjiang River, J. Water Sci. Technol., 15-17, 2010.
Kondolf, G.: Hungry water: Effects of dams and gravel mining on river channels, J. Environ Manage., 21, 533-555, https://doi.org/10.1007/s002679900048, 1997.

Lai, X., Yin, D., and Finlayson, B. L.: Will river erosion below the Three Gorges Dam stop in the middle Yangtze, J. Hydrol., 554, 24-31, https://doi.org/10.1016/j.jhydrol.2017.08.057, 2017.

Luo, X. X., Yang, S. L., Wang, R. S., Zhang, C. Y., and Li, P.: New evidence of Yangtze delta recession after closing of the Three Gorges Dam, J. Sci. Rep., 7, 41735, https://doi.org/10.1038/srep41735, 2017.

Magilligan, F. J. and Nislow, K. H.: Changes in hydrologic regime by dams, J. Geomorphology, 71, 61-78, https://doi.org/10.1016/j.geomorph.2004.08.017, 2004.

Qu, Y. Z., Liu, J. W., and Sun, G. S.: Change and analysis of sediment particles in lower reach of Yellow River before and after construction of Xiaolangdi Reservoir, J. Henan Water Conservancy and South-North Water Transfer, 66-67, 2010 (in Chinese).

Wang, W., Wang, X. G., and Zhou, X.: Impacts of Californian dams on flow regime and maximum/minimum flow probability distribution, J. Hydrol. Res., 42, 275289,https://doi.org/10.2166/nh.2011.137, 2011.

Xia, J., Deng, S., Lu, J., Xu, Q., Zong, Q., and Tan, G.: Dynamic channel adjustments in the Jingjiang Reach of the Middle Yangtze River, J. Sci. Rep., 6, 22802, https://doi.org/10.1038/srep22802, 2016.

Yang, S. L., Zhang, J., Dai, S. B., Li, M., and Xu, X. J.: Effect of deposition and erosion within the main river channel and large lakes on sediment delivery to the estuary of the Yangtze River, J. Geophys. Res., 112, F02005, https://doi.org/10.1029/2006JF000484, 2007.

Yang, S. L., Xu, K. H., Milliman, J. D., Yang, H. F., and Wu, C. S.: Decline of Yangtze River water and sediment discharge: Impact from natural and anthropogenic changes, J. Sci. Rep., 5, 12581, https://doi.org/10.1038/srep12581, 2015.

Zheng, S. W., Xu, Y. J., Cheng, H. Q., Wang, B., Xu, W., and Wu, S. H.: Riverbed erosion of the final 565 kilometers of the Yangtze River (Changjiang) following construction of the Three Gorges Dam, J. Sci. Rep., 8, 11917, https://doi.org/10.1038/s41598-01830441-6, 2018.

Zhou, Y. Q., Jeppesen, E., Li, J. B., Zhang, Y. L., Zhang, X. P., and Li, X. C.: Impacts of Three Gorges Reservoir on the sedimentation regimes in the downstream-linked two largest Chinese freshwater lakes, J. Sci. Rep., 6, 35396, https://doi.org/10.1038/srep35396, 2016. 